\title{
Foreign Direct Investment: A time of Indian Economy
}

\author{
Dr. A K Ray ${ }^{1}$,Dipayan Ghosh ${ }^{2}$ \\ ${ }^{1}$ (Professor, Department of Humanities and Social Science, National Institute of Technology, Agartala, India) \\ ${ }^{2}$ (Doctoral Research Scholar, Department of Humanities and Social Science, NIT, Agartala, India)
}

\begin{abstract}
Foreign direct investment is an important driver in the development process of a country. Over the past half a century, perceptions of the role played by foreign direct investment in the development process has undergone several changes. The present study has taken a sweeping glance of FDI inflow and outward FDI from India. Developing countries like India need substantial foreign inflows to achieve the required investment to accelerate economic growth and development. The first-tracked liberalization of the India economy was introduced in 1991 brought with a radical shift in the policy towards FDI. Foreign investment would bring attendant advantages of technology transfer, marketing expertise, introduction of modern managerial techniques and new possibilities for promotion of exports. FDI is needed for the interest of the country's industrial development. In the recent time FDI is considered to be the most attractive type of capital flow for India's emerging economies as it is expected to bring latest technology and enhance production capabilities of the economy. At the same time, a growing impetus for change today is coming from developing countries and economies in transition, where a number of private as well as state owned enterprises are increasingly undertaking outward expansion through foreign direct investments. Indian companies are expanding their business operations by investing overseas with a view to acquiring a regional and global reach.
\end{abstract}

Keywords: Foreign Direct Investment, FDI Inflow, Outward FDI, Trend

What is FDI?

\section{Introduction}

" An investor based in one Country acquires an asset in another country with the intent to manage the asset" (OECD,2000) $)^{1}$

FDI may give the opportunity to a developing country to bring non-debt creating foreign capital resources, technology up gradation, skill enhancement, new employment, spillovers and allocative efficiency effects. FDI is important for capital formation and filling the gap between domestic saving and investment.

FDI is an important driver for economic growth and development. The unprecedented growth at global FDI in 1990 around the world make FDI an important and vital component of development strategy in both developed and developing nations and policies are designed in order to stimulate inward flows. Direct investment tends to involve a lasting relationship, although it may be a short-term relationship in some cases with decisions by enterprises may make for the group as a whole.

\section{Fdi In India}

The historical background of FDI in India can be traced back with the establishment of east India Company of Britain. British capital came to India during the colonial era of Britain in India. Before independence major amount of FDI came from the British Companies. After Second World War, Japanese companies entered into the Indian market and enhanced their trade with India, yet U.K remains the most dominant investor in India. However, researcher could not portray the complete history of FDI pouring in India due to lack of abundant and authentic data.

Over the past half a century, perceptions of the role played by Foreign Direct Investment (FDI) in the development process has undergone several changes. Policy regime is the main factor driving foreign investment inflows to a country. Perceptions of foreign investors towards India changed quite distinctly as a result of the change in the policy regime. Inflows of FDI have increased substantially compared to the earlier regime in which the scope for FDI was quite restricted.

There has been a sea change in India's approach to FDI from the early 1990s when it began structural economic reforms encompassing almost all the sectors of the country.

\section{Pre- Reform Period}

With the objective of becoming self reliant, there was a dual nature of policy intention- FDI through foreign collaboration was welcomed in the areas of high technology and high priorities to build national capability and discouraged in low technology areas to protect and nurture the domestic industries. The regulatory framework was consolidated through the enactment of Foreign Exchange Regulation Act (FERA), 
1973 wherein foreign equity holding in a joint venture was allowed only up to $40 \%$. Drawing from success of other country experiences in Asia, Government not only established Special Economic Zones (SEZs) with a view to promote exports. But also designed liberal policy and provided incentives for promoting FDI in these zones with a view to promote exports. As India continued to be highly protective, these measures did not add substantially to export competitiveness. Recognizing these limitations, partial liberalization in the trade and investment policy was introduced in 1980 with the objective of enhancing export competitiveness, modernization and marketing of exports through Trans-national corporations (TNCs). The announcements of Industrial policy (1980 and 1982) and Technology Policy (1983) provided for a liberal attitude towards foreign investments in terms of Changes in policy directions. The policy was characterized by de-licensing of some of the industrial rules and promotion of Indian manufacturing exports as well as emphasizing on modernization of industries through liberalized imports of Capital goods and technology.

After independence the cautious FDI policy was resulted in a low level of FDI inflow in India. The amount of FDI increased from US\$ 79 million in 1980 to reach a peak level US \$ 252 million in 1989 thereafter it declined US \$ 237 million in 1990 (Table 1). The overall FDI inflow during 1980 to 1990 was fluctuating. FDI increased three times during the period of 1980-1990 and the CAGR (actual) was19.05\% during the same period of time (G.Akhtar, IJHSSI, 2013) ${ }^{2}$.

Table 1: FDI Inflow in India: Approval Vs Actual during 1980-90

\begin{tabular}{|l|l|l|l|}
\hline \multicolumn{1}{|l|}{ (US\$ million) } \\
\hline Year & Approval & Actual & \% growth (Actual) \\
\hline 1980 & 11.2 & 79.0 & - \\
\hline 1981 & 12.5 & 92.0 & 16.5 \\
\hline 1983 & 66.2 & 72.0 & -21.7 \\
\hline 1984 & 61.0 & 6.0 & -91.7 \\
\hline 1985 & 99.4 & 19.0 & 216.7 \\
\hline 1986 & 102.9 & 106.0 & 457.9 \\
\hline 1987 & 84.9 & 118.0 & 11.3 \\
\hline 1988 & 83.1 & 212.0 & 79.7 \\
\hline 1989 & 172.3 & 91.0 & -57.1 \\
\hline 1990 & 195.2 & 252.0 & 176.9 \\
\hline
\end{tabular}

Source: G. Akhter, IJHSSI ,UNCTAD, World Investment Report

\subsection{SECTOR-WISE BREAK-UP OF FDI INFLOW DURING PRE-REFORM PERIOD:}

The top five sectors which have attracted the bulk of FDI were industrial machinery, chemicals, mechanical engineering, electrical and electronics and metallurgy and together they accounted for $54.87 \%$ in the year 1981. In 1990, the top five sectors were electrical and electronics, chemicals, industrial machinery, mechanical engineering and metallurgy and together they accounted $68.14 \%$ of the total FDI inflows (Table 2).

Table: 2- FDI Inflows by Country of origin during 1981-1990

\begin{tabular}{|l|l|l|l|l|l|l|l|l|}
\multicolumn{1}{l|}{ In US\$ million) } \\
\hline $\begin{array}{l}\text { Year/Cou } \\
\text { ntry }\end{array}$ & USA & Germany & Japan & UK & Italy & $\begin{array}{l}\text { Switzerlan } \\
\text { d }\end{array}$ & Others & Total \\
\hline 1981 & 2.6 & 6.2 & 0.7 & 0.8 & 0.1 & 0.5 & 1.6 & 12.5 \\
\hline 1982 & 5.3 & 3.7 & 26.5 & 1.7 & 4.2 & 1.2 & 23.6 & 66.2 \\
\hline 1983 & 13.7 & 4.8 & 15.9 & 9.7 & 1.1 & 1.1 & 14.7 & 61.0 \\
\hline 1984 & 7.9 & 2.5 & 5.4 & 1.6 & 0.7 & 0.4 & 80.9 & 99.4 \\
\hline 1985 & 32.3 & 9.6 & 12.7 & 3.0 & 5.6 & 0.7 & 38.1 & 102.0 \\
\hline 1986 & 23.3 & 16.0 & 4.6 & 6.1 & 1.9 & 2.6 & 30.4 & 84.9 \\
\hline 1987 & 22.8 & 7.6 & 5.3 & 6.5 & 2.3 & 6.8 & 31.8 & 83.1 \\
\hline 1988 & 69.8 & 22.3 & 12.5 & 10.0 & 22.0 & 1.2 & 34.5 & 172.3 \\
\hline 1989 & 38.3 & 74.2 & 5.4 & 20.6 & 4.3 & 4.8 & 47.6 & 195.2 \\
\hline 1990 & 19.7 & 5.4 & 2.9 & 5.2 & 3.9 & 7.7 & 28.5 & 73.3 \\
\hline
\end{tabular}

Source: G. Akhter ${ }^{2}$, IJHSSI ,UNCTAD, World Investment Report

\section{Fdi Inflows In Post-Reform Period: Since 1991:}

After mid 1990 the political disturbances along with other economic problem gave rise to severe financial crisis in the Indian economy. The high rate of inflation, fiscal deficit and political instability downgraded the international credit of the country. This resulted in the erosion of the international community confidence on our economy. The outflow of deposits especially by NRIs, a virtual stoppage of remittances from Indian workers in the Gulf countries and a sudden break out of Gulf war in January 1991 exacerbated the balance of payments crisis. The foreign exchange became so scanty that, it was insufficient to pay even for one week imports. As a result the economic liberalization process was introduced under Structural Adjustment 
Programme (SAP) with the support of IMF and the World Bank. This culminated into a series of economic reforms in 1991 along with a host of industrial policy reforms. NIP 1991 recognized the role of FDI in the process of industrial development in India in terms of bringing greater competitiveness and efficiency and also modernization, technological upgradation, creation a sound base for export promotion and above all integrating India with rest of the world. The major highlights of NIP 1991 changes are as followings:

- Abolition of industrial licensing system except for 18 industries, which includes those industries which manufactured, hazardous chemicals and items of elitists consumption or of national concerns social well being and the environment concerns.

- Ceiling of 40 percent foreign equity under FERA was done away with.

- Removal of registration under MRTP Act.

- Foreign investment promotion board (FIPB) was established and has been authorized to provide a single window clearance for all project proposals regarded by it.

- Introduction of the dual approval system for FDI proposals viz. (i) through an automatic approval channel for FDI in 35 priority sectors by RBI upto equity participation 51 percent and (ii) through formal government of India channel via FIPB/SIA.

- Existing companies were allowed to hike their foreign equity upto 51 percent in priority sector.

- Dilution of dividend balancing conditions and its related exports obligation except in case of 22 consumer goods industries.

- Removal of restrictions of FDI in low technology sectors.

- Automatic permission for technology agreement in high priority industries.

- Removal of condition for FDI with necessary technology agreements etc.

Besides these in August 1999 government of India set up Foreign Investment Implementation Authority (FIIA) within the ministry of industry to facilitate quick translation of FDI approvals into implementation by providing a pro-active one step after care service to foreign investor like helping them obtain necessary approvals and sorting their operational problems. FIIA is assisted by Fast Track Committee which has been established in 30 Ministries/Departments of Government of India for monitoring and resolution of difficulties for sector specific

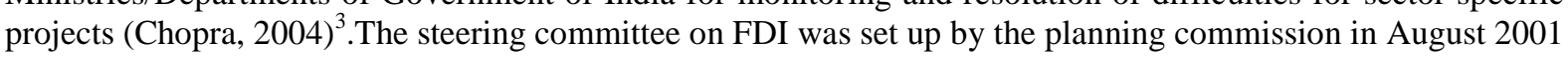
under Chairmanship of N.K. Singh which submitted its report in September 2002 to the Prime Minister. It recommended that the ban on FDI in retail trade should not be lifted while for other sector such as oil marketing, petroleum exploration, banking and financial services and real estate's was raised to limit of 100 percent (GulshanAkhtar, 2013).

Table 3: FDI in India: Approvals Vs Actual during 1991-2008

\begin{tabular}{|l|l|l|l|l|}
\hline Year & Approval & Actual & $\begin{array}{l}\text { Share of Inflows } \\
\text { Approval (percent) }\end{array}$ & percent growth (Actual) \\
\hline $1991-92$ & 527 & 165 & 31.31 & - \\
\hline $1992-93$ & 1976 & 393 & 19.89 & 138.18 \\
\hline $1993-94$ & 2428 & 654 & 26.94 & 66.41 \\
\hline $1994-95$ & 3178 & 1374 & 43.23 & 110.09 \\
\hline $1995-96$ & 11439 & 2141 & 18.72 & 55.82 \\
\hline $1996-97$ & 11484 & 2770 & 24.12 & 29.38 \\
\hline $1997-98$ & 10984 & 3682 & 33.52 & 32.92 \\
\hline $1998-99$ & 7532 & 3083 & 40.93 & -16.27 \\
\hline $1999-2000$ & 4266 & 2439 & 57.17 & -20.89 \\
\hline $2000-2001$ & 5754 & 2908 & 50.54 & 19.23 \\
\hline $2001-2002$ & 3160 & 4222 & 133.60 & 45.18 \\
\hline $2002-2003$ & 1654 & 3134 & 189.48 & -25.77 \\
\hline $2003-2004$ & 1353 & 2634 & 194.68 & -15.95 \\
\hline $2004-2005$ & 1913 & 3759 & 196.50 & 42.71 \\
\hline $2005-2006$ & 1610 & 5546 & 344.47 & 47.54 \\
\hline $2006-2007$ & NA & 15726 & - & 183.56 \\
\hline $2007-2008$ & NA & 24581 & - & 56.30 \\
\hline $2008-2009 *$ & NA & 27331 & - & 11.19 \\
\hline
\end{tabular}

Source: G. Akhtar, Economic Survey 2004-2005, Government of India

The 1991, New economic policy measures reversed the past policies to rebuild foreign investors confidence in making investment outlets in India. During initial years of the reform periods, there used to be a large gap between FDI pledged during approval and actual FDI inflows realized in the country (Table 3). Further, during this period, many sectors were kept outside the FDI and those sectors that were available for FDI were tagged with upper limit, and other terms and conditions in the form of special case-by-case approval if the FDI proposal was outside the automatic channel. Besides, investors were cautious about continuity of the policy changes in future. These factors led to the large difference in FDI actual inflows and approvals, which subsequently 
narrowed down during 1998 to 2000. As far as amount of FDI is concerned it has been increased from US\$ 165 million in 1991 to US\$ 4222 million in 2001, but thereafter it declined to US\$ 3134 and US\$ 2634 in the year 2002 and 2003 respectively. However 2004 it has shown increasing trend. Similarly, growth rate too fluctuated during 1991 to 2009. In the year 1998, 1999, 2002 and 2003 it was negative i.e. $-16.3,-20.9,-25.8$ and $-15.9 \%$ respectively. Thereafter it increased to a high level of in 2006 i.e. $183.56 \%$. The CAGR of actual FDI inflow is $24.28 \%$ during 1991-2008.

\subsection{Recent trends in FDI Inflows to India}

\section{FDI inflow in India}

With the tripling of the FDI flows to EMEs during the pre-crisis period of the 2000s, India also received large FDI inflows in line with its robust domestic economic performance. The attractiveness of India as a preferred investment destination could be ascertained from the large increase in FDI inflows to India, which rose from around US\$ 6 billion in 2001-02 to almost US\$ 38 billion in 2008-09. The significant increase in FDI inflows to India reflected the impact of liberalisation of the economy since the early 1990s as well as gradual opening up of the capital account. As part of the capital account liberalisation, FDI was gradually allowed in almost all sectors, except a few on grounds of strategic importance, subject to compliance of sector specific rules and regulations. The large and stable FDI flows also increasingly financed the current account deficit over the period. During the recent global crisis, when there was a significant deceleration in global FDI flows during 2009-10, the decline in FDI flows to India was relatively moderate reflecting robust equity flows on the back of strong rebound in domestic growth ahead of global recovery and steady reinvested earnings (with a share of almost 25 per cent) reflecting better profitability of foreign companies in India. However, when there had been some recovery in global FDI flows, especially driven by flows to Asian EMEs, during 2010-11, gross FDI equity inflows to India witnessed significant moderation. Gross equity FDI flows to India moderated to US\$ 20.3 billion during 2010-11 from US\$27.1 billion in the preceding year (RBI, 2011).

Table4: Equity FDI Inflows to India

\begin{tabular}{|c|c|c|c|c|c|}
\hline & & & & & (Percent \\
\hline Sectors & 2006-07 & $2007-08$ & 2008-09 & $2009-10$ & 2010-11 \\
\hline \multicolumn{6}{|l|}{ Sectoral shares (Percent) } \\
\hline Manufactures & 17.6 & 19.2 & 21.0 & 22.9 & 32.1 \\
\hline Services & 56.9 & 41.2 & 45.1 & 32.8 & 30.1 \\
\hline Construction, Real estate and mining & 15.5 & 22.4 & 18.6 & 26.6 & 17.6 \\
\hline Others & 9.9 & 17.2 & 15.2 & 17.7 & 20.1 \\
\hline Total & 100.0 & 100.0 & 100.0 & 100.0 & 100.0 \\
\hline \multicolumn{6}{|l|}{ Equity Inflows (US\$ billion) } \\
\hline Manufactures & 1.6 & 3.7 & 4.8 & 5.1 & 4.8 \\
\hline Services & 5.3 & 8.0 & 10.2 & 7.4 & 4.5 \\
\hline Construction, Real estate and mining & 1.4 & 4.3 & 4.2 & 6.0 & 2.6 \\
\hline Others & 0.9 & 3.3 & 3.4 & 4.0 & 3.0 \\
\hline Total Equity FDI & 9.3 & 19.4 & 22.7 & 22.5 & 14.9 \\
\hline
\end{tabular}

Source: $\mathrm{RBI}^{4}, 2011$

\subsection{Different route of FDI inflow in India}

FDI up to $100 \%$ is allowed under the automatic route in all the sectors except the following, which require prior approval of Government:

Sectors prohibited for FDI.

- Activities that require industrial license.

- Proposals in which the foreign collaborator has an existing financial/technical collaboration in India inthe same field.

- Proposals for acquisition of shares in an existing Indian Company in financial service sector and where SEBI regulations, 1997 is attracted.

- All proposals falling outside notified sectoral policy in which FDI is not permitted.

\subsubsection{Direct Investment:}

i) Equity

a) Government (SIA/FIPB)

b) RBI 

c) NRI
d) Acquisition of shares
e) Equity Capital
f) Unincorporated Bodies

ii) Re-invest Dearing

iii) Other Capital

\subsubsection{Indirect Investment:}

i) GDRs/ADRs

ii) FIIs

iii) Off-shore funds and others

\section{FDI Outflow}

\subsection{Outward Indian Foreign Direct Investment}

Outward FDI has been observed in the case of India in recent years. The emerging market economics become a source of foreign investment for the world. It is a sign of their increasing participation in the global economy and their increasing competence. Companies are from developing countries expanding their business operations by investing overseas with a view to acquire a regional and global reach.

\subsection{Factors motivating the outward foreign investments}

FDI is a natural extension of globalization process that often starts with exports. Globalization is a two way process, integration of the Indian economy with the rest of the world is evident not only in terms of higher level of FDI inflows but also in terms of increasing terms of FDI outflow. In the Indian context, overseas investments have been primarily driven by either resource-seeking or market-seeking of technology seeking motives. There has been a surge in resource-seeking overseas investments by Indian companies, especially to acquire energy resources in Australia, Indonesia and Africa.

\section{Material and Methodology}

\section{Objective of the Study:}

a. To estimate the factors influencing the FDI inflows in India

b. To understand the trends of outward FDI from India.

\section{Research Methodology}

The study is based on secondary data and the data has been collected from different publication of RBI, publications from Ministry of Commerce, Govt. of India, Economic and Social Survey of Asia and the Pacific, United Nations, Asian Development Outlook, Country Reports on Economic Policy and from different research studies.

\section{Model Building}

To study the factors influencing the FDI inflow in India the following model has been used

$\mathrm{FDI}=\mathrm{A}+\mathrm{B}_{1} \mathrm{X}_{1}+\mathrm{B}_{2} \mathrm{X}_{2}+\mathrm{B}_{3} \mathrm{X}_{3}+\mathrm{B}_{4} \mathrm{X}_{4}+\mathrm{B}_{5} \mathrm{X}_{5}+\mathrm{E}$

Where,

FDI- Foreign Direct Investment

A- Constant

$\mathrm{B}_{1}-\mathrm{B}_{5}-$ Various regression Parameters to be estimated

X1- Trade GDP

X2- Reserves GDP

X3- R\&D GDP

X4- Financial Health

X5- Exchange Rates 
VIII. Analytical Tables And Discussion

Table-5: India's foreign direct investment inflows and various economic indicators in between 1991 to 2010

\begin{tabular}{|c|c|c|c|c|c|c|c|c|}
\hline & & & & & & & unt in & Crore \\
\hline \multirow[t]{2}{*}{ Years } & \multirow{2}{*}{$\begin{array}{l}\text { Gross } \\
\text { Domestic } \\
\text { Product }\end{array}$} & \multirow[t]{2}{*}{ Total trade } & \multirow{2}{*}{$\begin{array}{l}\text { Foreign } \\
\text { exchange } \\
\text { reserves }\end{array}$} & \multirow{2}{*}{$\begin{array}{l}\text { Research } \\
\text { \&Development }\end{array}$} & \multicolumn{2}{|c|}{ Fin. Position } & \multirow{2}{*}{$\begin{array}{l}\text { Exchange } \\
\text { Rates }\end{array}$} & \multirow{2}{*}{$\begin{array}{l}\text { FDI } \\
\text { Inflows } \\
\text { in } \\
\text { India }\end{array}$} \\
\hline & & & & & Exports & Debts & & \\
\hline $91-92$ & 1099072 & 91892 & 23850 & 8386.31 & 44041 & 252910 & 24.5 & 409 \\
\hline $92-93$ & 1158025 & 117063 & 30744 & 8526.18 & 53688 & 280746 & 30.6 & 1094 \\
\hline $93-94$ & 1223816 & 142852 & 60420 & 9408.79 & 69751 & 290418 & 31.4 & 2018 \\
\hline $94-95$ & 1302076 & 172645 & 79781 & 9340.94 & 82674 & 311685 & 31.4 & 4312 \\
\hline $95-96$ & 1396974 & 229031 & 74384 & 9656.11 & 106353 & 320728 & 33.4 & 6916 \\
\hline 96-97 & 1508378 & 257737 & 94932 & 10662.41 & 118817 & 335827 & 35.5 & 9654 \\
\hline $97-98$ & 1573263 & 284276 & 115905 & 11921.83 & 130100 & 369682 & 37.2 & 13548 \\
\hline $98-99$ & 1678410 & 318084 & 138005 & 12967.51 & 139752 & 411297 & 42.1 & 12343 \\
\hline 99-00 & 1786525 & 374797 & 165913 & 14397.6 & 159561 & 428550 & 43.3 & 10311 \\
\hline $00-01$ & 1864301 & 434444 & 197204 & 15683.37 & 203571 & 472625 & 45.7 & 10368 \\
\hline 01-02 & 1972606 & 454218 & 264036 & 16007.14 & 209018 & 482328 & 47.7 & 18486 \\
\hline $02-03$ & 2048286 & 552343 & 361470 & 16353.72 & 255137 & 498804 & 48.4 & 13711 \\
\hline 03-04 & 2222758 & 652475 & 190129 & 17575.41 & 293367 & 491078 & 45.9 & 11789 \\
\hline $04-05$ & 2388768 & 876405 & 619116 & 19991.64 & 375340 & 581802 & 44.9 & 14653 \\
\hline 05-06 & 2616101 & 1116827 & 676387 & 22963.91 & 456418 & 616144 & 44.3 & 24613 \\
\hline 06-07 & 2871120 & 1412285 & 868222 & 24821.63 & 571779 & 746918 & 42.3 & 70630 \\
\hline 07-08 & 3129717 & 1668176 & 1237985 & 27213 & 655864 & 897955 & 40.2 & 98664 \\
\hline 08-09 & 3339375 & 2072438 & 1283865 & & 766935 & 1169575 & 45.9 & 123025 \\
\hline
\end{tabular}

Source: Swapna Hooda ${ }^{5}, 2011$ RBI Bulletins and SIA publication

Table 6: Result of FDI Inflow Model

\begin{tabular}{|l|l|l|l|}
\hline Variable & co-efficient & standard error & t-statistic \\
\hline Constant & 26.65 & 0.126 & $207 *$ \\
\hline TradeGDP & 11.79 & 7.9 & $1.5 *$ \\
\hline ReserveGDP & 1.44 & 3.8 & 0.41 \\
\hline Exchange Rate & 7.06 & 9.9 & $0.72 * *$ \\
\hline Financial Health & 15.2 & 35 & 0.45 \\
\hline R\&D GDP & -582.14 & 704 & $0.83^{* *}$ \\
\hline
\end{tabular}

Note: $*$ = Significant at $0.25,0.10$ levels; $* *=$ Significant at 0.25 level.

In Foreign Direct Investment Model, it is found that all variables are statistically significant. Further the results of Foreign Direct Investment Model shows that TradeGDP, R\&DGDP, Financial Position (FIN. Position), exchange rate (EXR), and ReservesGDP (RESGDP) are the important macroeconomic determinants of FDI inflows in India. The regression results of above shows that TradeGDP, ReservesGDP, Financial Position, exchange rate are the pull factors for FDI inflows in the country whereas R\&DGDP acts as the deterrent force in attracting FDI flows in the country. As the regression results reveal that R\&DGDP exchange rate does not portray their respective predicted signs. However, R\&DGDP shows the unexpected negative sign instead of positive sign and exchange rate shows positive sign instead of expected negative sign. In other words, all variables included in the foreign direct investment model shows their predicted signs except the two variables (i.e. Exchange rate \& R\&DGDP) which deviate from their respective predicted signs. The reason for this deviation is due to the appreciation of Indian Rupee in the international market and low expenditure on R\&D activities in the activities in the country.

\section{Trend of FDI outflow}

Since 1992, industrial deregulation, trade liberalization and relaxation of regulations governing inward FDI, led to major restructuring in the Indian industry. Overseas investment by Indian companies is not only a phenomenon of 1990s. Indian firms began to invest overseas in 1960s, but India's respective policies for overseas investment limited them to small, minority joint ventures in developing economies. First major overseas Indian venture was a textile mill set up in Ethiopia in 1959 by the Birla Group of Companies (Athukorala ${ }^{6}$, RBI Bulletin, 2012). Overseas investment operations were geographically concentrated in west 
and East Asia with which India shared a colonial heritage and historical linkages. Sustained growth in Indian overseas investment could be seen starting during 1970s when the industrial licensing system was more stringent.

Many of the leading companies owe their competitiveness to the reform process. Greater exposure to internal as well as external competition proved to be instrumental in building confidence among the Indian companies to compete with foreign competitors in world market. Apart from liberalized policy environment for overseas investment, India has gained ground as an important investor on the back of

a) Rapid economic growth

b) Easy access to financial resources

c) Strong motivations to acquire resources and strategic assets

Table 6: Top ten Country- wise overseas investments by Indian Companies

\begin{tabular}{|l|l|l|l|}
\multicolumn{2}{c}{ (Amount in billion US Dollar) } \\
\hline Country & $\mathbf{2 0 0 8 - 0 9}$ & $\mathbf{2 0 0 9 - 1 0}$ & $\mathbf{2 0 1 0 - 2 0 1 1}$ \\
\hline Singapore & 4.06 & 4.20 & 3.99 \\
\hline Mauritius & 2.08 & 2.15 & 5.08 \\
\hline Netherlands & 2.79 & 1.53 & 1.52 \\
\hline United States of America & 1.02 & 0.87 & 1.21 \\
\hline United States of Emirates & 0.63 & 0.64 & 0.86 \\
\hline British Virgin lands & 0.00 & 0.75 & 0.28 \\
\hline United Kingdom & 0.35 & 0.34 & 0.40 \\
\hline Cayman Islands & 0.00 & 0.04 & 0.44 \\
\hline Hong kong & 0.00 & 0.00 & 0.16 \\
\hline Switzerland & 0.00 & 0.00 & 0.25 \\
\hline Other countries & 7.65 & 3.19 & 2.65 \\
\hline Total & 18.58 & 13.71 & 16.84 \\
\hline Source & & \\
\hline
\end{tabular}

Source: Harun $\mathrm{Khan}^{8} 2012$

Table-7 Year wise position of actual outflow

\begin{tabular}{|l|l|l|l|l|l|}
\hline Period & Equity & Loan & Guarantee Invoked & Total & Guarantee Issued \\
\hline $2000-2001$ & 602.12 & 70.58 & 4.97 & 677.67 & 112.55 \\
\hline $2001-2002$ & 878.83 & 120.82 & 0.42 & 1000.07 & 155.86 \\
\hline $2002-2003$ & 1746.28 & 102.10 & 0.00 & 1848.38 & 139.63 \\
\hline $2003-2004$ & 1250.01 & 316.57 & 0.00 & 1566.58 & 440.53 \\
\hline $2004-2005$ & 1481.97 & 513.19 & 0.00 & 1995.16 & 315.96 \\
\hline $2005-2006$ & 6657.82 & 1195.33 & 3.34 & 7856.49 & 546.78 \\
\hline $2006-2007$ & 12062.92 & 1246.98 & 0.00 & 13309.90 & 2260.96 \\
\hline $2007-2008$ & 15431.51 & 3074.97 & 0.00 & 18506.48 & 6553.47 \\
\hline $2008-2009$ & 12477.14 & 6101.56 & 24.18 & 18578.70 & 3322.45 \\
\hline $2009-2010$ & 9392.98 & 4296.91 & 52.49 & 13714.07 & 7603.04 \\
\hline $2010-2011$ & 9234.58 & 7556.30 & 0.00 & 16843.37 & 27059.02 \\
\hline
\end{tabular}

Source: HR Khan, $2012^{8}$

The above trend analysis shows that the level of outward FDI from India has increased manifold since 19992000. The level of net outward FDI flows recorded a sharp uptrend at US\$ 74.3 billion during the second half on 2000s (2005-06 to 2009-10) as compared to US\$ 8.2 billion in the first half of 2000s (2000-01 to 2004-05). Even though trend in Indians outward FDI moderately affected during the crisis year of 2009-10, a sharp rebound was seen in 2010-11 (Table 6 and Table 7).

The overseas investment by overseas companies has also expanded as India was placed second in 2010 only after china in terms of average size of net purchase deals (US\$190 million in India as compared to US\$ 197 million in China). Similarly, India also figures among the top five emerging and developing economics whose state-owned enterprises are increasingly becoming transitional corporations. It is not surprising as in recent years, India public sector units viz., NTPC, GAIL, ONGC and NALCO have undertaken significant overseas green-field investments.

\section{Sectoral Investment}

Sectoral pattern of outward FDI during 2006-07 to 2010-11 shows that it has been mainly invested in services and manufacturing sector. In 2010-11 (Table 8), within manufacturing, major sub-sectors which attracted outward FDI from India included agriculture machineries and equipments, basic organic chemicals, drugs, medicines and allied products, refined petroleum products, indigenous sugar, etc. Similarly, within services sector, a majority of outward FDI had gone into business services, data processing, financial services, architectural and engineering, engine architectural and other technical consultancy activities (UNCTAD ${ }^{7}, 2009$ ). 
Table-8: Major sector-wise overseas investments

\begin{tabular}{|l|l|l|l|}
\hline Period & $\mathbf{2 0 0 8 - 0 9}$ & $\mathbf{2 0 0 9 - 1 0}$ & Amounts in billion US D-11 \\
\hline Manufacturing & 10.18 & 5.35 & 5.04 \\
\hline $\begin{array}{l}\text { Financial Insurance, Real Estate } \\
\text { Business \& Business Services }\end{array}$ & 3.55 & 4.41 & 6.53 \\
\hline $\begin{array}{l}\text { Wholesale \& Retail trade, restaurants } \\
\text { and Hotels }\end{array}$ & 1.17 & 1.13 & 1.89 \\
\hline Agriculture and allied activities & 2.38 & 0.95 & 1.21 \\
\hline $\begin{array}{l}\text { Transport, communication and storage } \\
\text { services }\end{array}$ & 0.31 & 0.38 & 0.82 \\
\hline Construction social \& personal & 0.39 & 0.36 & 0.38 \\
\hline $\begin{array}{l}\text { Community, } \\
\text { services }\end{array}$ & 0.18 & 0.70 \\
\hline Electricity, Gas \& Water \& & 0.14 & 0.84 & 0.10 \\
\hline Miscellaneous & 0.12 & 0.11 & 0.18 \\
\hline Total & 18.58 & 13.71 & 16.84 \\
\hline
\end{tabular}

Source: Harun R Khan, RBI,2012, UNCTAD

India might be the largest source of emerging market of multinational enterprises (MNEs) by 2024. By this period, number of MNEs would be higher than china by $20 \%$, and over 2200 Indian firms are likely to invest overseas in the next fifteen years (PWC, 2010).

\section{Conclusion:}

Perceptions of foreign investors towards India changed quite distinctly as a result of the change in the policy regime. Inflows of FDI have increased substantially compared to the earlier regime in which the scope for FDI was quite restricted. The policy changes were thus aimed at improving India's record in attracting FDI inflows, which was seen to be below its potential, particularly when compared with the massive inflows reported by China. The progressive liberalization of the foreign investment policy as well as the steps to improve the investment climate could thus be seen as attempts to overcome this perceived failure to match initial expectations and also in comparison with China. Even though global economies are suffering with financial crisis and other economic hurdles, India still stands as a global investment destination. Keeping in view of current requirements and benefits of the nation the government of India comes up with new policies from time to time. It is observed from the results of above analysis that Trade GDP, Reserves GDP, Exchange rate, FIN. Position, R\&DGDP and FDIG are the main determinants of FDI inflows to the country. It is an important source of economic development for country whereas some people see threat of FDI to sovereignty of host and domestic business houses. Policy makers need to ensure transparency and consistency in policy making along with comprehensive long term development strategy. In case of outflow, the Indian companies become increasingly competitive; they may aggressively explore globalization opportunities as part of their future growth plans. Outward FDI related to acquisition of strategic resources, expansion of markets etc. would facilitate in long term growth in India and absorption of technology by Indian corporate along with improvements in the managerial skills.

\section{Reference}

[1] KS Rao, BiswajitDhar (2011) -“India's FDI Inflows Trends and Concepts”; OECD, Benchmark Definition of foreign Direct Investment, Fourth Edition 2008.

[2] G. Akhtar, 2013- "Inflows of FDI in India: Pre and Post reform period" International Journal of Humanities and social science Invention, Vol.2 Issue-2.

[3] Chopra, Chanchal (2004) -“FDI in India: Liberalization and WTO-The emerging scenario," Deep and Deep publication pvt.Ltd.

[4] http://www.rbi.org.in/scripts/AboutusDisplay.aspx

[5] SapnaHooda (2011)- A study of FDI and Indian Economy.

[6] Athukorala, Prema-Chandra (2009), “Outward FDI from India, Asian development review," Vol.26, No 2

[7] UNCTAD (2009), world Investment prospects Survey 2009-2011, United Nations conference on Trade and Development, New York.

[8] H R Khan (2012), "Outward Indian FDI- Recent Trands and Emerging Issues."

[9] PWC (2010), "Emerging Multinationals: The rise of new multinational companies from emerging economies." 